\title{
The Largest European Blackberry Producer: A Research Case Study on Entrepreneurship and Family Business
}

\author{
Ajay Chauhan \\ President University \\ ajay@ president.ac.id \\ Alfonso Vargas-Sánchez \\ Huelva University \\ vargas@uhu.es \\ María Moral-Moral \\ Cádiz University \\ maria.moral@uca.es
}

\begin{abstract}
The present paper is based on a field research on the evolution of a saga of family entrepreneurs in Spain, with four generations involved. From the modest beginnings of a canned tomato factory, longer than a century ago, the case explains its transformation up to the current reality of being recognized as the largest blackberry European producer, named 'Agrícola El Bosque'. Through the personal experience of its main characters, the case displays the very different stages through which this entrepreneurial family has traveled, especially the keys to the successful development of 'Agrícola El Bosque', including the last major project that has promoted, based on a process of cooperation with other berries producers in the area. This commercial alliance, branded as 'Plus Berries', leads us to reflect on the future of the growth model followed until now by this family business. On the foundations of this case, some lessons can be extracted and shed light on particular aspects of the scientific literature on family business management, as well as on how entrepreneurial spirit can be fed and flourish at the heat of the development and consolidation of a cluster of companies in an industry.
\end{abstract}

Keywords: Entrepreneurship, Family Business, Strategy, Agriculture, Europe.

\section{Introduction}

As a matter of fact, family businesses constitute the vast majority of the productive fabric worldwide. Family firms are common across sizes and industries, ranging from the smallest producers to the largest multinationals and from agriculture to services industries, containing, therefore, an enormous diversity. In a nutshell, this is the prevalent organizational form, "considered to be the backbone of private industry and a key target for policies aimed at increased employment and economic growth" (Andersson et al., 2017).

Although little consensus still exists among researchers regarding the definition of a family firm, and significant efforts to reach a shared understanding have been done, going into this debate.is not part of the aims of this paper. The case used here 
undoubtedly fits the mold of a family firm, whatever the definition taken: a company almost fully owned and in practice under the management of the members of a family (two brothers, one of them having the majority stake, and their father, basically).

The above-mentioned firm is "Agrícola El Bosque, S.L.", of particular interest for having been identified as the largest blackberry European producer, located in the Southwest of Spain. Our sincere thanks go to this family for opening their doors to us and devoting their time to numerous interviews and work sessions, which were carried out in situ during the months of January-February 2017. This piece of research, which we present with their approval, would not have been possible without their collaboration. In addition to documents provided by family members involved in the business and information available via the company website and on the Internet, the SABI database has proven to be a further source of information for this research case.

As a family of entrepreneurs, entrepreneurship is another lens used to examine this case. Being considered a driver of competitiveness and jobs creation, it has also extensively attracted the attention of researchers and politicians, having been promoted by the latter through a variety of public policies.

In the academic field, entrepreneurship and strategy have usually been two intertwined subjects. For example, the Entrepreneurial School is one of the strategy approaches, of descriptive nature, declared by Mintzberg et al. (1998). This has been the approach implemented in this case, having paid particular attention to the strategic intents and positioning of this family business. In fact, as concluded by Harrington et al. (2014), the topic "entrepreneurship and strategy" has been identified as one of the dominant themes (fifteen in total) in the scientific field of strategic management, after having tracked all the papers published from 2011 through 2013 (three years period) in the three following journals devoted to research on strategic management only: Strategic Management Journal, Strategic Entrepreneurship Journal, and Global Strategy Journal, all of them associated with the Strategic Management Society.

Therefore, based on the research under study and its practical implications, this manuscript is aimed to contribute to the discussion on a number of issues raised by this case with regards to entrepreneurship and family business management.

In this line, this article is structured in the subsequent sections: first of all, the case will be presented, followed by a discussion about its implications on the promotion of entrepreneurship and the strategic management of a family business. Some final remarks are intended to shed some light on the main conclusions gathered.

\section{Field Works: The Case of 'AGRÍCOLA EL BOSQUE'}

In the next subsections, the research case on the largest blackberry production company in Europe will be summarized, organized as follows: firstly, a reference to its family roots and background, in an attempt to present the entrepreneurial DNA of this saga; secondly, the origins of the company under study (Agrícola El Bosque) when the fourth generation of entrepreneurs arrives, with new ideas and motivations; thirdly, the first steps, the evolution and management approach of this family business; in fourth place the last and fundamental phase in its development, still undergoing, is outlined, based on a strategic alliance with some complementary producers, also family businesses; and finally, a glance into the future, with a reflection about its main challenges ahead and how to deal with them. 


\subsection{History: An Entrepreneurial DNA}

The history of the family business we now know as Agricola El Bosque S.L. dates back to the end of the 19th century, a time when tomato production in the Huelva region (Spain) was on the increase and excess production reached such levels that Agustín Velo Romero, great-grandfather of those who run the company today, decided to market tomato preserves under the name "La Canastita" (The Little Basket), a brand name that his great-grandchildren would reclaim roughly one hundred years later. La Canastita produced high-quality, natural peeled tomatoes that had been prepared in bain-marie (by women, it is worth noting).

The founder of this manufacturer of preserved vegetables initiated a long line of entrepreneurs from the municipality of Bonares; entrepreneurs who have known how to adapt to the passage of time and the changes that this inevitably brings.

This was a time in which English entrepreneurs had acquired the Riotinto mining deposits and the Rio Tinto Company Limited, as the mining company was called at the time, had a virtually all-pervading influence on the development of a significant part of the Spanish province of Huelva. The sharp business acumen of Agustín led him to establish contacts among the English staff of the company with the aim of exporting his preserves to the United Kingdom; an aim he was to achieve, by the way.

Along the way, the first hurdle to be overcome turned out to be the poor quality of the Spanish tin used to package the preserves at the time, which tended to oxidise easily. However, the dynamism of Agustín led to a business arrangement in which the English supplied tin (from England, naturally) that was suitable for preserving the packaged product in optimum conditions. However, the die-casting machines owned by the factory at the time did not possess sufficient power or capacity to mould English tin and produce the required packaging. Not to be discouraged, Agustín searched for alternatives and eventually acquired German die-casting machines that were up to the task.

In the 1930s the tomato crop in the region contracted a serious disease which wiped out the entire production, the result being that the plants were torn up and replaced with vines. In light of this Agustín was obliged to adapt to the situation and converted his business into that of a wine merchant, for which he purchased grapes of the autochthonous variety 'zalema' and produced wine, which he sold locally. The characteristics of these wines, however, made them difficult to market.

While some time later Diego and José Velo García, sons of founder Agustín Velo Romero, would continue in the wine trade, it was Diego Velo García who would take over the reins of the company and convert the family business into an agriculture and livestock enterprise on an estate of approximately 330 hectares dedicated to grazing land, rearing pigs and cultivating olives. The estate was located in the municipalities of Lucena del Puerto and Bonares, at the very gates of the Doñana National Park, considered today the largest nature reserve in Europe, and declared a World Heritage Site by Unesco in 1994. The livestock in question were Iberian pigs, dark and elongated, which were sold live, and while the grazing lands produced cork every 8 or 9 years, the sale of which helped boost the company's finances, the olive groves were little more than a marginal activity.

In the 1960s another setback affecting the livestock would halt the progress of the family business, namely the propagation of a disease thought to be African swine fever, 
which is highly contagious in swine herds and led to the slaughter of the entire herd by order of the authorities at the time, though it was later discovered that it had not, in fact, been the African swine fever virus. This would signal the beginning of a new activity on part of the estate known as "El Bosque" (The Woods), a higher-altitude section with an extension of 160 hectares located in the municipality of Lucena del Puerto that had been inherited by Diego Velo García following the distribution of Agustín Velo Romero's estate, and which was now dedicated to cow milk production. This business decision was basically prompted by the type of food eaten by the variety of cattle acquired, which allowed the family to make use of the acorns produced on the estate. Another aspect worth highlighting is the peculiarity of using acorns to feed the cattle, which led to these animals producing yellowish-coloured milk from which it was easier to produce cream. The inquisitive nature of Diego Velo García (son of the founder) led him to attempt to diversify the livestock herds by introducing sheep and goats, but the characteristics of the soil on the estate did not allow for rapid regeneration of fodder for feed and the experiment was discontinued. The result was that livestock breeding only lasted a few years and activity on the estate reverted to the production of olives and cork.

One of the most critical moments in the history of the family business came with the inheritance of the agriculture and livestock activity, which was continued by Diego Velo Castillo, grandson of founder Agustín, who collaborated with his father (Diego Velo García) in the upkeep and management of the estate. Diego Velo Castillo, the third generation of owners, finished his university studies as a builder's surveyor in 1965 and, following a number of jobs including one in Ceuta city, his first destination following his successful civil service examinations for the National Housing Institute, became a civil servant in the Huelva administration. While his professional activity was not directly linked to agriculture his desire was to maintain the estate rather than sell it. As he himself tells it, the family business had been changing and making ends meet by "performing experiments", in allusion to the fact that the estate had adapted to changing circumstances via a process of trial and error.

\subsection{Fourth Generation: The Germination of AGRÍCOLA EL BOSQUE}

However, the most far-reaching transformation of the family business, that which would lead to the founding of Agrícola El Bosque S.L. as we know it today, would occur in the 1990s by the hand of Javier Velo Prieto (the fourth generation), son of Diego Velo Castillo and great-grandson of the founder. Javier's bond with the agricultural activities of his family had begun in childhood, at which time he experienced early and regular contact with country life. This could be considered a key factor in future developments as it would determine his decision to train as a Technical Agricultural Engineer, a qualification that would allow him to apply all his academic experience to the family business and eventually turn it around. His fondness for the estate was such that he eventually decided to live there.

Even before completing his university studies, and as the result of experiments carried out on an estate in Moguer, Javier became interested in the cultivation of berries other than the traditional strawberries the region is noted for. In 1995, this restless nature led him to become involved in a personal project that was somewhat risky at the time, that of opting for the production of blackberries. In his own words, "After so much study and effort I didn't feel like doing what everyone else was doing. I wanted to do something different. I wanted a personal motivation, something to fight for." 
At the time few estates were dedicated to the cultivation of blackberries and extensions were limited to approximately 10 hectares. The perishable nature of the variety of blackberries being cultivated led to rapid deterioration in both the appearance and quality of the fruit harvested, which prevented transportation to outlets located at any significant distance from the production areas and excluded not only consumers from the rest of Europe but also from other parts of Spain (the produce would barely make it to Madrid, for instance).

Despite this drawback, Javier understood that he would have to opt for a crop that was not currently being cultivated in the region and that would stand out from the remainder of the products characteristic to the area, strawberry mainly, while at the same time making the most of some of the synergies that had been handed down from years of accumulated experience with this flagship product. In this context his decision was determined by his personal motivation to take on the challenge of revitalising an estate that had so far been underutilised. To some extent he later followed in the footsteps of his great-grandfather by reclaiming the brand name, the latter had used for his preserved tomatoes: "La Canastita".

As a result of his investigations, he was able to identify a number of key factors for the development of his project: on the one hand, the opportunity to be able to make to most of the existent inertia in the berry market (strawberries as well as other berries that were beginning to emerge, such as raspberries and cranberries) in the Huelva province, for which logistics and distribution networks had already been developed and were in operation, meaning that contacts with potential distributors and customers were easier to establish. On the other hand, there were the characteristics of the estate itself, which contained lands that, in addition to other forestry produce, could also be adapted for this crop. The fact was that the income generated from cork extraction gave the estate a certain financial cushion with which to develop the cultivation of blackberries.

Blackberry cultivation began on a half-hectare extension with an investment of 2 million pesetas at the time (some 12,000 euros) and in the first year produced some 500 $\mathrm{kg}$ of fruit. The first years were difficult, marked as they were by both research into new varieties and experimentation with these new varieties using the time-honoured strategy of trial and error in an effort to verify behaviours and degrees of adaptation and single out the varieties that were the most durable and produced and highest quality fruit. In addition to identifying the varieties that best adapted to the agro-climatic conditions of the area, from a commercial perspective these would also have to respond to the preferences and shopping habits of the European consumer, given that, from the beginning, the principal European countries were chosen as the target market for reason of their high level of purchasing power.

In 1998 Javier's younger brother, Daniel Velo Prieto, joined the family enterprise; his training as a Technical Industrial Engineer complementing that of his brother, who focussed primarily on administrative duties. To clarify the generational succession, the Velos' family tree follows (Figure 1). 


\section{Velo's family tree}

1st generation

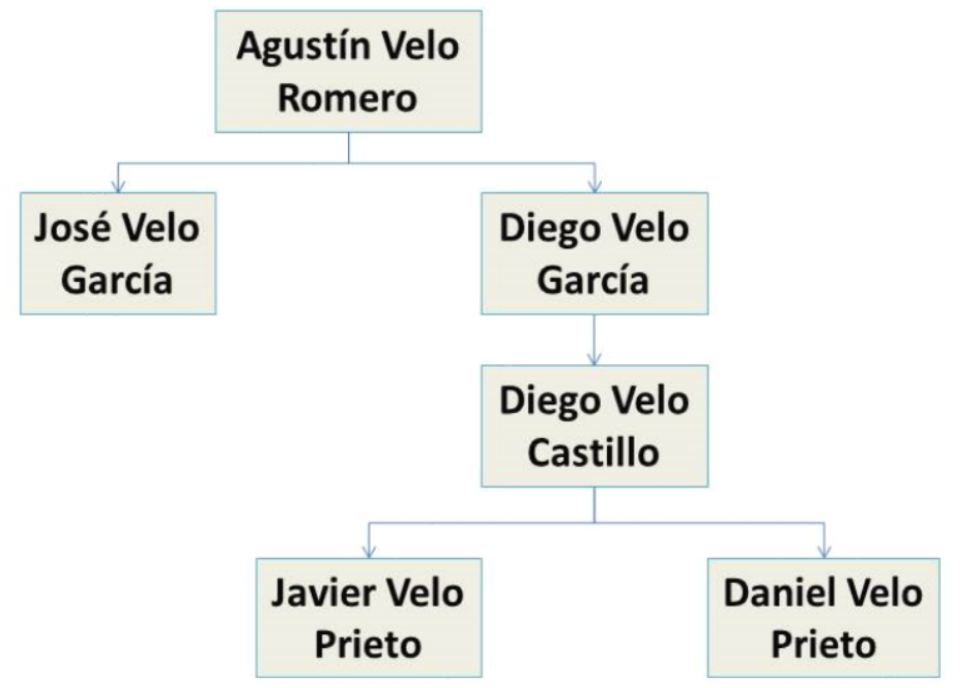

Figure 1: Velo's Family Tree

\subsection{AGRÍCOLA EL BOSQUE Takes Shape}

And so, we arrive at the year 2001, when the company Agrícola El Bosque S.L. is formally established and blackberries begin to be distributed under the brand name "La Canastita" (The Little Basket), thereby reclaiming the name of the original tomato preserves produced by Agustín.

Javier himself admits that the passage of time has allowed the family to identify company's values that, despite being inherent to the enterprise since its origins and spontaneously manifesting themselves, have never been explicitly and formally defined. Among these we may highlight the following:

a) Ongoing improvement in both the end product and the processes implemented in the company as a means of working towards excellence.

b) Facing the difficulties and problems that arise within the company with spirit and enthusiasm and adopting a positive attitude towards them without giving in to discouragement.

c) Team-wide professionalism and integrity.

d) Creation of a climate of trust and respect and the forging of good relationships between employees and the family project by developing a positive working environment.

e) An ongoing desire to improve and offer a product that has been tailored to both the demands of the market and the preferences of the consumer.

f) Commitment to and development of sustainable agricultural practises that are respectful of the natural surroundings in which the activity takes place. 
g) The creation of value and shared wealth for the social context of the company as a business model.

h) Acknowledgement of the need for both collaboration and the creation of synergies with other berry sector companies as a means of ensuring continued growth and success.

On a strategic level, the Iberian Balance Sheet Analysis System (SABI, in Spanish) offers some relevant information. In it the activity of Agrícola El Bosque S.L. is described as "the production and commercialisation of berry fruits (blackberries and other high-quality berries)". Following on from this database, together with the information provided by the company, seven local competitors were identified (competition from companies in other parts of Spain is considered not relevant as their production is limited to the summer harvest). In this context, Javier estimates that the current market share of his company is around $60 \%$.

That said, Agrícola El Bosque S.L. is noted for a level of specialisation that has led it to become the only company on a national level to exclusively produce and market blackberries all year round. The company philosophy has but one fundamental objective: "to offer the best, highest-quality blackberries".

In order to achieve this, the production system employed is based on the application of a cutting-edge technology that consists of hydroponic cultivation in containers hung across trellises in macro-tunnel greenhouses with control of climate variables and heating ("you have to deceive the plant in order for it to produce fruit out of season"). In addition, the company possesses an in-house R\&D department that focuses its efforts on the search for varieties that will improve production, the qualitative and organoleptic properties of the fruit and the shelf life. To this end Agrícola El Bosque S.L. allocates a production area for the carrying out of tests and trials.

It is also worth noting that the company has participated and continues to participate in a number of national and international research projects, some examples of which are:

1) Project 1: The increase and stabilisation in blackberries of content containing bioactive compounds using bio-effectors (period: 01/01/2013 - 28/02/2015; budget: $474,811 €)$.

2) Project 2: Resource Efficient and Safe Food Production and Processing (period: 01/11/2012 - 31/10/2015; budget: 237,384.10€).

3) Project 3: Growing Berries (period: 01/06/2013 - 31/03/2015; budget: 200,509.66€).

4) Project 4: Improvement of food quality and safety in pre- and post-harvest using biocontrol tools and emergent technologies (period: 01/10/2015 - 31/12/2017; budget approved: $125,685 €)$.

A focus on original production techniques combined with a commitment to innovation and R\&D has led Agrícola El Bosque S.L. to become a leading sector company that has obtained a competitive advantage over its competitors by eliminating the seasonality of its product, becoming the only Spanish company to produce blackberries all year round.

In addition, the company's production, shown in Table 1 is characterised by a firm commitment to the environment that includes avoiding negative impacts of production, ensuring optimal use of natural resources, irrigation water and drainage system recirculation techniques and optimisation of rainwater gathering. As Diego Velo 
Castillo states, "We're very close to Doñana [National Park], we have to be sustainable."

Table 1: Blackberry production of Agrícola El Bosque S.L. Evolution in recent years.

\begin{tabular}{|c|c|}
\hline Year & Output (kg) \\
\hline 2012 & 310.610 \\
\hline 2013 & 449.250 \\
\hline 2014 & 524.876 \\
\hline 2015 & 684.368 \\
\hline 2016 & 778.250 \\
\hline
\end{tabular}

Source: the company.

The company's vision is firmly entrenched in the company philosophy of commitment to agricultural development that is compatible with the preservation of natural values and the rational use of resources. What is more, a percentage of the company benefits are invested in the community in which the business activity takes place in an effort to both meet the needs of the employees and alleviate their concerns.

The workforce of Agrícola El Bosque S.L. currently (2016) consists of 31 full-time employees and an average of 600 temporary workers per year over an extension of 70 hectares of production. The continual increase in the number of employees, operating revenue and company profits can be seen in the Table 2, these being the result of a strategy based on innovation and international commercialisation/promotion of the product. However, as Javier states, "our policy regarding growth has always been conservative", confessing that "we are beginning to see results, but the early stages were difficult as production was limited [barely six weeks] and there were many trips to Holland and Belgium in the search for new varieties, much trial and error... so growth has been gradual."

Table 2: Principal figures for Agrícola El Bosque S.L.

\begin{tabular}{|c|c|c|c|}
\hline Year & Operating revenue (Euros) & Profit (Euros) & $\mathrm{N}^{\circ}$ employees* \\
\hline 2001 & 786,010 & 92,962 & 12 \\
\hline 2002 & 703,247 & 68,837 & 14 \\
\hline 2003 & 809,675 & 9,102 & 30 \\
\hline 2004 & 910,347 & 15,515 & 34 \\
\hline 2005 & $1,425,714$ & 103,812 & 40 \\
\hline 2006 & $1,832,685$ & 83,782 & 40 \\
\hline 2007 & $2,320,347$ & 106,378 & 44 \\
\hline 2008 & $2,537,923$ & 476,135 & 48 \\
\hline 2009 & $1,877,236$ & 184,732 & 45 \\
\hline 2010 & $2,917,602$ & 588,672 & 59 \\
\hline 2011 & $3,093,824$ & 590,276 & 50 \\
\hline 2012 & $3,753,933$ & 525,555 & 51 \\
\hline 2013 & $5,182,939$ & 674,208 & Not available \\
\hline 2014 & $6,362,907$ & 830,868 & 282 \\
\hline 2015 & 7.542 .979 & 1.018 .005 & 271 \\
\hline
\end{tabular}

* Average number of people employed over the course of the financial year, according to Annual Accounts (info available in the company reports).

Source: SABI online (2017) 
Human resources management is strongly influenced by a company culture that encourages respect for the employee, a reality that is borne out by the fact that Agrícola El Bosque S.L. is one of the first agricultural companies to carry out studies on its own working environment and to monitor this environment on a periodical basis. Agrícola El Bosque S.L implements policies that favour both equal opportunities for men and women and the contracting of workers from disadvantaged social sectors. As a result of these policies the workforce is $50 \%$ female and the company continues to generate both direct and indirect employment for young people from nearby areas. Also, as part of this culture it is worth mentioning that some $5 \%$ of company shares have been distributed among employees who have had a long and special relationship with the family and held key positions within the company, thereby demonstrating a commitment to involving all personnel in the company's activities and using internal promotion as a core element of its human resources policy.

This initiative of hiring young staff and involving them in the business allows the company to reap the benefits of more highly trained and creative people, who are both open to innovations and more committed to the company. At the same time the company contributes to keeping the rural population in the area, thereby reducing the progressive ageing of the local population.

\subsection{Plus Berries: Collaboration and Ties in The Berry Sector}

Plus, Berries began in 2012 when four family businesses from the Spanish province of Huelva, all of them comprising young farmers and dedicated to the production of berry fruits (among them Agrícola El Bosque S.L.), decided to join forces and collaborate in the production and sale of their four flagship products (blackberries, cranberries, raspberries and strawberries) in agricultural and food trade fairs and exhibitions.

The initial seed for the idea, however, goes back three years earlier to 2009, when Agrícola El Bosque felt the need, as Javier says, "to go out and meet the customer". To this end the company sent a proposal to other companies in the area, suggesting they jointly attend the first edition of Fruit Attraction in Madrid, a trade fair they eventually attended in conjunction with Frutas Hermanos Pulido S.L. (specialists in cranberries) and with the aid of Extenda, the Andalusian Agency for Exterior Promotion. They soon realised that the customers themselves, in this case distributors and intermediaries, were interested in other types of berry (strawberries and raspberries) and were keen to know if these companies (Agrícola El Bosque and Frutas Hermanos Pulido) formed part of any kind of group, a fact that would allow them to procure various types of berry in a single negotiation and consequently save on transaction and administration costs.

This acknowledgement by the customers themselves brought to light the advantages to be gained by joining forces with other sector companies in the commercialisation of berries both in an effort to be more competitive and to promote the sale of their products on an international level. The following year, in 2010, the company Frutas Remolino S.L. (specialists in raspberries) joined the initiative while attending the Fruit Attraction trade fair.

Later still, in February of 2012, Agro Martín S.L., an important strawberry producer from the same area, also joined the project, bringing the total of specialist, high-quality berry producers who had joined forces in an effort to jointly market their produce to four. 
In July of 2013 the initiative was consolidated and strengthened through the foundation of a Spanish legal entity known as a Society for Agrarian Transformation (S.A.T. in Spain), in this case under the name Plus Berries, a fact that allowed the four companies to unify their business administration. The main reason for choosing this particular legal format was that it allowed them to be incorporated into a Spanish O.P.F.H. (Organisation of Producers of Fruits and Vegetables), a legal entity that would allow them to benefit from the public subsidies available for this type of organisation. Plus, Berries offices are located in the Huelva Science and Technology Park (PCTH) in the municipality of Aljaraque.

In order to understand the Plus Berries decision making and strategic management processes one has to bear in mind not only the distribution of the company's property but also the manner in which the assignment of duties has been allocated among the various heads, or managers, of each production company, who are also specialists in the particular fruit their company handles and assume responsibilities relating to sales management, $\mathrm{R}+\mathrm{D}+\mathrm{i}$ and varietal development, among other tasks. In this organisation the figure of 'head' or 'general manager' does not exist, but rather the day-to-day management in each area is handled by the person responsible in accordance with strategic directives that have been agreed upon by all the partners, who generally hold a coordination meeting every two weeks or so in order to exchange views and discuss the direction the group should be taking.

The collaboration and union among these companies, which has materialised in the incorporation of the S.A.T. Plus Berries, is based on the joint acknowledgement of a series of ideas. On the one hand, a commitment to specialisation and differentiation of each of the production companies (the concept that each company is a specialist in one type of fruit is passed on to the customer), and, on the other hand, the development of a joint project designed to both strengthen the image of the produce and promote international expansion. Along these lines, as Javier states, "the choice of partners was determined by the search for a specific profile."

In this regard, Agrícola El Bosque S.L. has been the principal driving force behind the creation of Plus Berries, the conception of which was the result of the analysis of the sector environment carried out by Javier Velo, who soon came to the realisation that in order to widen the choice of fruit offered to the customer and better respond to their demands the creation of Plus Berries was essential both on a strategic level and for the survival of his company. As Javier states, "a mono-berry model was not the best way to go, we had to lean towards a multi-berry model". To this one could add a context in which the largest cooperatives in the region (the principal competitors) were leaning towards the commercialisation of a variety of berries, which led Javier to the understanding that they had to extend their offer in order to gain presence in the market and consolidate the business activity.

The implementation of this strategy has led to significant savings in logistics and advertising for the four group companies. Plus, Berries regularly attend important sector trade fairs the likes of Fruit Attraction in Madrid and Fruit Logistica in Berlin. In events of this nature each company maintains its own identity within the group.

The Plus Berries sales strategy, therefore, is all about presenting a fresh, up-to-theminute image in which the berries produced by each company are the principal protagonists. This is reflected in the Plus Berries logo, which includes a colour representing each of the four separate companies and berries in which they specialise. 
In the words of Daniel Velo: "the group is the sum of the individualities and personalities of each member". Each partner possesses an open, innovative way of thinking that complements the other members, a philosophy that is passed on to the day-to-day administration of Plus Berries, where the commercialisation of each type of berry (blackberry, strawberry, raspberry and cranberry) is the responsibility of whoever is effectively the sales manager of the company that specialises in and produces the particular product. This strategic decision allows the sales team for the company specialising in a particular fruit to maintain a hands-on approach and keep up to date with the reality of the operation. As Javier has said, "we are specialist producers, and that means bringing the land closer to the customer."

In order to achieve this, an active sales policy adapted to the target markets has been developed through the creation of new sales catalogues, a new website with information available in Spanish and English (http://www.plusberries.com/) and even the production of flyers designed to help acquaint the younger members of the family with the numerous type of berries that exist by presenting them with "the incredible adventures of the super-berries". The group also implements 'inverse' sales missions in which customers are invited to the various estates in order to gain hands-on knowledge of what day-to-day life is like on the farms in an effort to improve and consolidate the image of the four companies in the international, principally European, markets

The incorporation of Agrícola El Bosque S.L. into Plus Berries has led the company to participate, along with the other group partners, in both sales missions in various countries, these being organised by Extenda, the Andalusian Agency for Exterior Promotion, and 'inverse' missions such as that carried out in 2013 as part of the $4^{\text {th }}$ edition of Andalusia Sabor (International Fine Food Exhibition), where it was the only fresh fruit company participating in the event.

Presence of the Plus Berries group in sector trade fairs such as the aforementioned Fruit Attraction and Fruit Logistica is a central element of the group's international expansion policy and has facilitated the establishment of business relationships with the Asian market, which in turn have led to the freighting of berries to Malaysia, Indonesia and Singapore, among other markets.

In 2014 the group's expansion strategy was well on the way to consolidating both its presence in European and Middle Eastern markets and its penetration in the HORECA Channel (a syllabic abbreviation of the words HOtel/REstaurant/CAfé).

In 2015 Plus Berries strengthened its commercial ties by increasing the number of sales missions undertaken by the partners to Great Britain, Ireland and Central European countries, a fact that has led to further increases in exports.

The development of new packaging by the group (e.g. BerryBowl and Rhythm\&Blue) is yet another example of its commitment to differentiation and ongoing improvement as a means of meeting the needs of its customers.

In recent years Plus Berries has progressively expanded via the incorporation of new partners the likes of Tilla Berries (June 2014), a cranberry producer, a fact that has increased the group's capacity to meet increased demands of this product, and, more recently, Caver Explotaciones y Servicios S.L., an Extremadura-based producer of stone fruits (drupes) whose experience in the sales to new markets, especially foreign markets, is now at the service of the other partners, thereby increasing the number of varieties of fruit that the group can offer its customers. 
The incorporation of Tilla Berries and Caver as new members of Plus Berries has improved the diffusion and promotion of the group's produce to new customers, a fact that is reflected in the group structure. On analysis of information from 2014 taken from the SABI database, one can appreciate three levels of participation (taking into account direct and indirect participations where applicable): Agrícola El Bosque S.L., Agro Martín S.L. and Frutas Remolino S.L. having majority participation, with $26.63 \%$, $26.65 \%$ and $26.63 \%$ respectively, the second level consisting of Frutos Hermanos Pulido S.L., and Tilla Berries S.L., with $8.61 \%$ each, and finally Caver Explotaciones y Servicios S.L., with $2.87 \%$

More recently, in 2016, the Plus Berries group established further contacts that have given rise to new business relationships with supermarket chains, as is the case with Mercadona in Spain, for which La Canastita, the brand name of Agrícola El Bosque S.L., has become a supplier. La Canastita also supplies important UK supermarket chains the likes of Tesco, Asda and Marks \& Spencer, among others.

These notable efforts in promotion and sales by the members of the group have both led to increased demand for these products, principally in European countries, and given rise to an increase in the hectares dedicated to the cultivation of these fruits. This increase in demand has also been motivated by the existence of a formidable competitor in the form of Mexican producers that are able to market their produce in Europe at low prices thanks to favourable currency exchange rates and low production costs, despite the costs of air freight. What could be considered as a threat to Plus Berries, however, has in fact become an opportunity, for two reasons: first of all, the poorer quality of fruit produced by the Mexican companies, and, secondly, the delays experienced by orders sent from Mexico, both of which have motivated European customers to look for other suppliers that can guarantee both quality and delivery schedules.

All in all, the implementation of the Plus Berries initiative can be highlighted as a model of cooperation and union among sector companies; a model that, thanks to the joint efforts of all those involved, allows the member companies to approach evermore demanding and competitive international markets with greater guarantees of success.

Creativity, innovation, ongoing product improvement and customer satisfaction are issues that have influenced and defined the direction and focus of the Plus Berries group and the companies that comprise it. These values have allowed for the creation of synergies and added value for all the constituent companies thanks to an entrepreneurial vision that allows them to unite resources and skills in an effort to move forward and together constitute a greater presence in the international berry market.

Proof of the original nature of the initiative and its significance for the local economy has been the recent recognition awarded to Plus Berries as Huelva business of the year 2016, an award given in recognition of the importance of the group to the province as an ambassador of the Huelva brand name to the international markets in which the group operates.

\subsection{AGRÍCOLA EL BOSQUE and Its Future}

Predicting or anticipating the future in any business venture is an increasingly complex task, as is any attempt to predict what may happen even in the short term. And as if this were not sufficient, to the traditional uncertainty regarding market behaviour we must add the difficulties inherent to the development of any agricultural activity, in which factors such as the unpredictability of meteorological conditions or the response that a 
particular variety of berry may have may significantly affect the final production of a crop and, in consequence, customer and end-consumer satisfaction. All these circumstances must therefore be taken into account.

Where strategic aspects are concerned, it is worth noting that the principal challenge of Agrícola El Bosque S.L. resides in maintaining customer interest in the product, making fruit attractive by producing and marketing all types of berry, all year round. As Javier is quick to point out, "The customer is never loyal".

This particular vision is what makes "varietal development" one of the top priorities of Agrícola El Bosque S.L. - varietal development being the search for in-house varieties that respond to the needs and demands of the consumer, who require high-quality fresh fruit all year round. Management considers this to be a fundamental aspect of protecting the company from the increase in offers that will inevitably arise in the future.

To a significant extent this priority is determined by the Velo brothers' perception of the berry sector, where they predict an oversizing of the offer. For this reason, the efforts and concerns of Agrícola El Bosque S.L. are focussed on attaining excellence through the research and development of in-house varieties of better-quality, tastier blackberries.

Along these same lines, as a constituent member of Plus Berries, a secondary priority of the company strategy is to consolidate the differentiated offer marketed by the group, through each of its partners, by maintaining close ties with distributors that the company considers essential in terms of ensuring that their product reaches the end consumer; effectively they allow the company to position itself successfully in the competitive European market by making it possible for their berries to reach supermarkets and hypermarkets.

Within a context of disintermediation by both parties, Javier Velo is of the opinion that "the direct model is interesting if it possesses the right dimension, but this is not the case in point." For this reason, he feels that the niche to aim for is "to provide a good service to the importer, combined with varietal development that allows us to offer our customers an exclusive product." In parallel, and in order to remain competitive with regard to 'third countries', he considers it equally important on a strategic level to continue working towards optimisation of production costs.

Transformation of fresh produce is seen as a long-term option, as "alternative capabilities would be required if we were to approach a different business model", and this would require some type of alliance with industrial enterprises as "the level of investment would be huge."

On this point, and faced with the risk of oversupply, a situation which is likely to occur in the relatively near future, the Velo brothers, while they consider themselves prepared, also wonder if, in effect, Agrícola El Bosque S.L. is in the best position to face the downward spiral of prices that this scenario would doubtless bring.

Likewise, they ask themselves to what degree the organisational and managerial structure of Plus Berries is suitable or compatible with the incorporation of new partners who would either force a break with the original idea of a specialised company for each type of berry, or require, as has happened previously, broadening the area of activity of the company to include other products. In other words, "should they maintain the current structure and not admit more partners, or should they change the structure to 
allow the incorporation of new partners in an effort to increase their size and reinforce their negotiating position in the markets?"

\section{Implications of The Case}

Nowadays, family businesses are influenced by extremely competitive and complex environments, where globalization of markets and technological changes affect their survival severely.

In this context, following to Helsen et al. (2017), it is important to recognize that the organizational and management forms of this type of businesses are largely determined by the emotional aspects of family members, which significantly affect decision making in the company. Specifically, the case of Agrícola El Bosque SL shows how the current managers 'attachment and interest for the agricultural activity initiated by their predecessors became the germ of the experienced transformation and growth of the family business, with their close affective ties, feelings and commitment acting as one of the drivers of the competitiveness achieved.

This emotional linkage represents a stimulus for overcoming difficulties and for the development of processes of continuous improvement, favoring the company's adaptation to changes in an increasingly complex business reality. Therefore, academic literature focuses on the importance of family values and emotional aspects in the management of family business. In fact, new concepts have been formulated, such SocioEmotional Wealth (SEW), introduced about 10 years ago to describe "the nonfinancial aspects of the firm that meet the family's affective needs" (Gomez-Mejia et al., 2007, p.106). In this line, Kraus et al. (2016) point out the influence of SEW in the processes of internationalization implemented in the context of family businesses. Precisely, in the present investigation the significant effect exerted by this variable on the survival and success of the company under study has been highlighted, being a European reference in the blackberries sector.

Academics have also offered another perspective of the effects of family members' emotional connections, which can give rise of one of the classic handicaps attributed to this kind of firms: the inefficient decision making based on family ties, adopting strategies that favor and satisfy firstly members of the family (Memili et al., 2015; Parker et al., 2016). Therefore, the establishment of corporate governance mechanisms are crucial to reduce these potential negative effects (Kumar and Zattoni, 2016), leading to greater professionalization of family and non-family managers (Diéguez Soto et al., 2016). In the case of Agrícola El Bosque SL, it is observed how the family experience has been made compatible with the professionalization of its human team, and, in addition, there is a business vision committed to the creation of synergies with other companies in the berry sector based on commercial alliances, which has led to the creation of SAT Plus Berries, in which its strategic management is supported on a shared assumption of tasks distributed among its corporate members.

Furthermore, according to Stenholm et al. (2016), Entrepreneurial Orientation (EO) understood as the commitment to innovation, proactivity or risk taking- is a variable that has a positive effect on the growth of family businesses, taking into account that a higher or lower level of EO is determined by the preservation of the SocioEmotional Wealth (SEW) in the family business (Garcés-Galdeano et al., 2016). It is remarkable that Entrepreneurial Orientation can be considered as a key factor in the growth and success of the company in this investigation. 
However, one of the difficulties facing family businesses usually is the problem of the succession of their leaders (Parker, 2016). In our opinion, the promotion of an Entrepreneurial Orientation (EO) within the family business is determinant for the business continuity, being necessary to promote the assumption of entrepreneurial values within the business, considering the relevance of this variable. Additionally, nonfinancial motivations, such as the development of a culture of effort and improvement, as well as the link between successor and entrepreneur initiated by the founder, have been posited in the literature as determinants in the continuity of family businesses (Parker, 2016). Samei and Feyzbakhsh (2015) consider necessary in the successor's profile competencies as: open-mindedness, risk-taking, trustworthiness, communication skills, value orientation and motivation, factors which are recognizable in the managers of the analyzed company.

On the other hand, in the case of family enterprises, the generation of new knowledge and Research \& Development (R\&D) activities is often placed in a secondary level, mainly due to the limited availability of resources and as a result of traditional managerial approaches that still prevail in many cases (Memili et al., 2015). Nevertheless, this factor is presented here as a key to the success and leadership position currently occupied by the Agrícola El Bosque SL as a European producer of blackberries, having been able to make its product available to the consumer all year round, breaking with the seasonality which presents this crop thanks to its participation in a number of R\&D projects and the corresponding technological innovations which have been implemented.

At the strategic level, it should be pointed out that the theory of stakeholders is present in the relationships maintained by this family enterprise with multiple interest groups (i.e., clients, employees, local community, partners, etc.), betting for the development of socially responsible policies and actions focused on various agents. As examples, its hiring policy as well as its commitment to applied research aiming to the development of new varieties and products in favor of greater customer satisfaction. Therefore, family values, social environment and training of managers have had a significant impact on the consolidation of a socially responsible behavior.

Also, at strategic level, a very remarkable feature of this case is the successive transformations suffered by the family business, although always within the agroindustry: from the initial tomato preserves factory to the current cultivation of blackberries one century later, with other economic activities in between (winery, livestock raising -pigs and later cows mainly- and production of cork and olives). Basically, each new generation promoted a new activity, providing fresh ideas and a significant capacity to adapt the family business to new market demands and adverse circumstances (such as crop or animal diseases).

This fact leads us to underscore the followings:

First is the capacity, disseminated from generation to generation, to take new risks when dealing with new activities, to adapt the business to new circumstances through a logic based on trial and error, is a characteristic of the abovementioned EO (Zahra et. al, 2006), in which the ability to learn, and transferred that learning to family members, can be considered as essential. This process of learning transfer is facilitated by the fact that the activity carried out has been always related to agriculture.

Second is the capacity to change and evolve, to reinvent and revitalize the family business from generation to generation, is tackled by the dynamic capabilities approach, 
as an outstanding branch of the resource-based view of the firm. In this field, the contribution of Jones et al. (2013) is intended to demonstrate how multigenerational ownership (such as in Agricola El Bosque SL) contributes to the creation of dynamic capabilities in family firms. Nevertheless, May (2013) argues that family farm run businesses have fewer opportunities to develop these capabilities than firms belonging to other industries.

In this sphere, Chirico and Nordqvist (2010) highlight the crucial role of organizational culture; specifically, family inertia is considered to be a factor preventing the creation of dynamic capabilities, and family inertia depends on characteristics of the family business culture, where paternalism and entrepreneurial orientation influence family inertia positively and negatively, respectively. Consistently, the business culture of Agrícola El Bosque has been one of the most outstanding elements drawn in our research, providing support to this previous finding.

\section{Conclusion}

This paper conducts a qualitative research on a family of entrepreneurs in Spain in order to highlight the various aspects that have contributed to its current position as the largest blackberry European producer. Consequently, the evolution of this family business over time, on its own way to success, has been presented, allowing us to establish the various contributions of this case, both related to theoretical approaches and practical management implications. The conclusions obtained are as follows:

Firstly, to emphasize that Entrepreneurship Orientation (EO) is a crucial variable for the survival and growth of family enterprises, so that the leaders' entrepreneurial commitment contributes to the identification of and adaptation to new opportunities of business and the development of innovations, as suggested by Stenholm et al. (2016).

Secondly, to underline the importance of developing dynamic capabilities in the family business, when its EO leads to its evolution, even reinvention, in order to survive and succeed facing changing circumstances. To this purpose, the learning capacity and the ability to transfer that learning from generation to generation raises as a fundamental factor. This transfer of knowledge from leader to leader is favored by the family character of the business and the affective link towards the business felt by family members (when there is no conflict between generations, as in our case).

Thirdly, the impact of so-called SocioEmotional Wealth (SEW) on decision-making is noteworthy. It is remarkable the importance that the family and emotional ties exert in the management of the analyzed family enterprise, conditioning the decision making and the setting of objectives. It also establishes lines of business action focused on sustainability and responsible engagement with stakeholders and, in general, the environment in which it operates.

Fourthly, the practical implications are aimed to recommend the business model that represents Agrícola El Bosque SL, where the commitment to technological innovation and the creation of synergies with other companies have been postulated as determining to achieve its internationalization and its leading position in the blackberries sector. It is suggested to carry out benchmarking exercises in other sectors of activity, in agriculture mainly, due to the results and success of this company.

Finally, among the limitations of this paper, the geographical and sectorial context of the company analyzed, as contingent factors, can be mentioned, which leads to recommend future research focused on other sectors and countries to identify other 
family business models, due to their heterogeneity, which will allow a better assessment of their management as well as of the role and contribution of this type of firms in their economies. 


\section{References}

Andersson, F.W.; Johansson, D.; Karlsson, J.; Lodefalk, M.; Poldah, A. (2017). The Characteristics and Performance of Family Firms: Exploiting information on ownership, governance and kinship using total population data. Working paper 1/2017. Örebro University, School of Business. Available at: https://www.oru.se/globalassets/oru-

sv/institutioner/hh/workingpapers/workingpapers2017/wp-1-2017.pdf

Chirico F.; Nordqvist M. (2010). Dynamic capabilities and transgenerational value creation in family firms. The role of organizational culture. International Small Business Journal, 28(5), 487-504.

Diéguez-Soto, J.; Duréndez, A.; García-Pérez-de-Lema, D.; Ruiz-Palomo, D. (2016). Technological, management, and persistent innovation in small and medium family firms: The influence of professionalism. Canadian Journal of Administrative Sciences, 33, 332-346.

Garcés-Galdeano, L.; Larraza-Kintana, M.; García-Olaverri, C.; Makri, M. (2016). Entrepreneurial orientation in family firms: the moderating role of technological intensity and performance. International Entrepreneurship and Management Journal. 12(1), 27-45.

Gomez-Mejia, L.; Haynes, K.; Nuñez-Nickel, M.; Jacobson, K.; Moyano-Fuentes, J. (2007). Socioemotional wealth and business risks in family-controlled firms: Evidence from Spanish olive oil mills. Administrative Science Quarterly, 52(1), 106-137.

Harrington, R.J.; Chathoth, P.K; Ottenbacher, M.; Altinay, L. (2014). Strategic management research in hospitality and tourism: past, present and future. International Journal of Contemporary Hospitality Management, 26(5), 778808.

Helsen, Z.; Lybaert, N.; Steijvers, T.; Orens, R. (2017). Management control systems in family firms: a review of the literature and directions for the future. Journal of Economics Surveys, 31(2), 410-435.

Jones, O.; Ghobadian, A.; O’Regan, N.; Antcliff, V. (2013). Dynamic capabilities in a sixth-generation family firm: Entrepreneurship and the Bibby Line. Business History, 55(6), 910-941.

Kraus, S.; Mensching, H.; Calabrò, A.; Cheng, C-F.; Filser, M. (2016). Family firm internationalization: A configurational approach. Journal of Business Research, 69, 5473-5478.

Kumar, P.; Zattoni, A. (2016). Editorial: Family Business, Corporate Governance, and Firm Performance. Corporate Governance: An International Review, 24(6), 550-551.

May, D.E. (2013). Explaining Family Farm Run Businesses' Capacity to Develop Dynamic Capabilities. International Journal of Sustainable Economies Management, 2(1), 12-25.

Memili, E.; Fang, H.; Chrisman, J.J.; De Massis, A. (2015). The impact of small- and medium-sized family firms on economic growth. Small Business Economics, 45(4), 774-785. 
Mintzberg, H.; Ahlstrand, B; Lampel, J. (1998). Strategic Safari. New York: The Free Press, New York.

Parker, S.C. (2016). Family Firms and the "Willing Successor" Problem. Entrepreneurship Theory and Practice, 40, 1241-1259.

Samei, H.; Feyzbakhsh, A. (2015). Predecessors competency framework for nurturing successors in family firms. International Journal of Entrepreneurial Behavior and Research, 21(5), 731-752.

Stenholm, P; Pukkinen, T.; Heinonen, J. (2016). Firm Growth in Family BusinessesThe Role of Entrepreneurial Orientation and the Entrepreneurial Activity. Journal of Small Business Management, 54(2), 697-713.

Zahra, S.A.; Sapienza, H.J.; Davidsson, R. (2006). Entrepreneurship and Dynamic Capabilities: A Review, Model and Research Agenda. Journal of Management Studies, 43(4), 917-955. 